\title{
THREE YEARS OF MISTNETTING BIRDS IN THE EASTERN QU'APPELLE VALLEY
}

JOHN POLLOCK, Box 353, Whitewood, SASKATCHEWAN. SOG 5C0

During the summer of 1992, 1993 and 1994 I operated a Monitoring Avian Productivity and Survivorship (MAPS) station in a coulee in the Qu'Appelle Valley near Whitewood. MAPS is an international cooperative bird monitoring program that began in 1989. MAPS was created to closely monitor bird populations (primarily songbirds) by netting birds throughout the breeding season. The study's main objective is to determine the species composition within specific habitat types and to deter- mine their productivity (the ratio of young successfully fledged to adult birds) and survivorship (the ratio of birds returning to breed from year to year). With concerns about declining songbird populations, MAPS aims to determine if these declines are a result of poor productivity on the breeding grounds, changing climatic conditions or loss of habitat on the wintering grounds. There are approximately 300 MAPS stations in United States and Canada at this time.

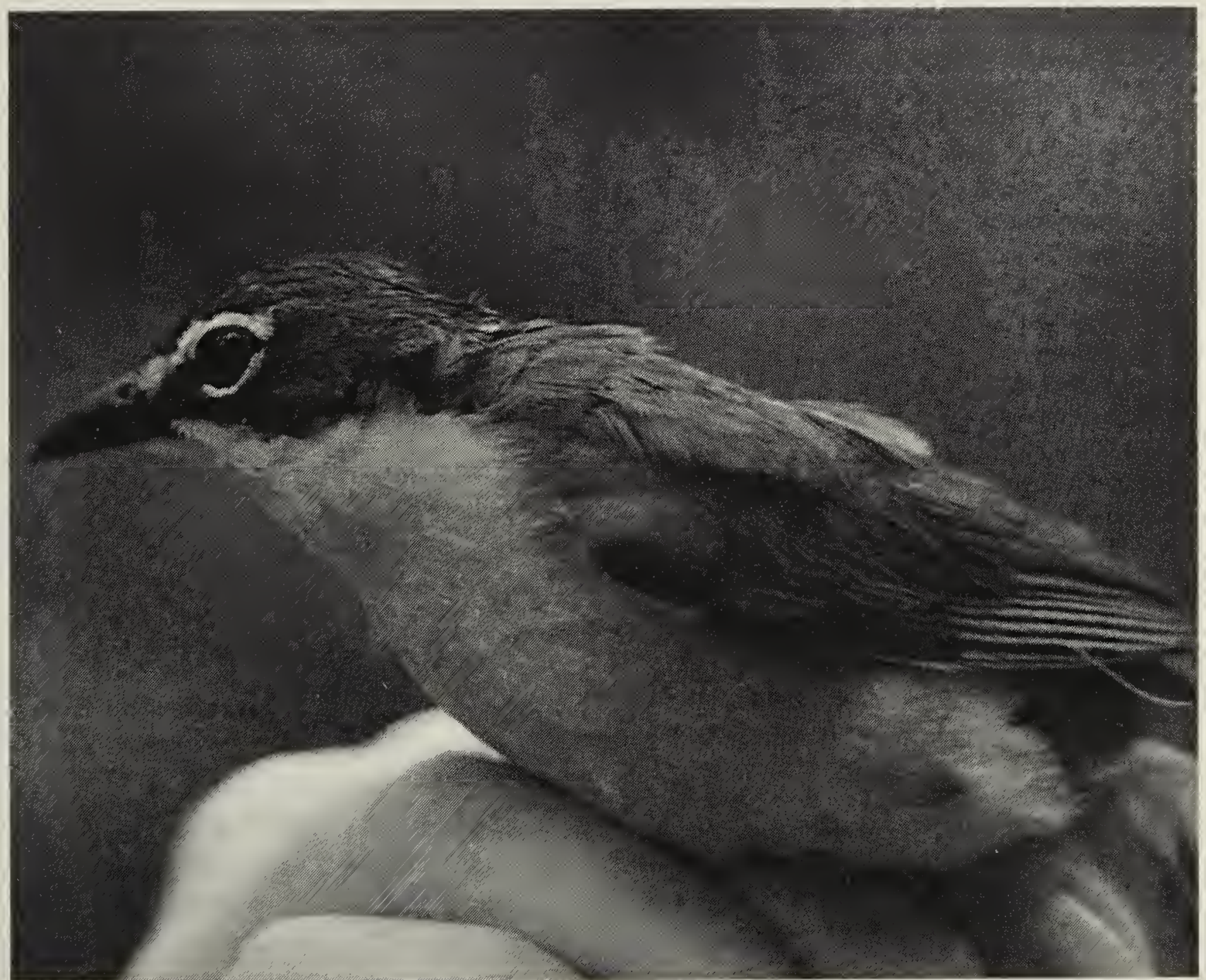




\begin{tabular}{|c|c|c|}
\hline \multicolumn{3}{|c|}{$\begin{array}{l}\text { Table 1. BIRDS OCCURRING IN OR ADJACENT } \\
\text { TO STUDY AREA IN 1992, } 1993 \text { AND/OR } 1994\end{array}$} \\
\hline Breeding in Study Area & $\begin{array}{c}\text { Occurred in Study Area and } \\
\text { known to breed in } \\
\text { adjacent habitat }\end{array}$ & $\begin{array}{c}\text { Other birds occurring in } \\
\text { Study Area (insufficient } \\
\text { data to determine breeding) }\end{array}$ \\
\hline Ruffed Grouse & American Bittern & Common Loon \\
\hline Alder Flycatcher (10) & Canada Goose & Pileated Woodpecker \\
\hline Least Flycatcher (22) & Mallard & Eastern Wood-Pewee \\
\hline Eastern Kingbird & Sharp-shinned Hawk & Great-crested Flycatcher \\
\hline Black-capped Chickadee (14) & Red-tailed Hawk & Common Raven \\
\hline Veery (19) & Killdeer & Tennessee Warbler (11) \\
\hline Gray Catbird (4) & Marbled Godwit & Nashville Warbler (4) \\
\hline Cedar Waxwing (2) & Common Snipe & Wilson's Warbler (3) \\
\hline Red-eyed Vireo (32) & Black-billed Cuckoo (1) & Canada Warbler (2) \\
\hline Orange-crowned Warbler (10) & Mourning Dove & Yellow-breasted Chat (1) \\
\hline Yellow Warbler (11) & Ruby-throated Hummingbird & \\
\hline Black-and-white Warbler (14) & Yellow-bellied Sapsucker & \\
\hline American Redstart (38) & Hairy Woodpecker (1) & \\
\hline Ovenbird (12) & Eastern Phoebe & \\
\hline Northern Waterthrush (18) & Western Kingbird & \\
\hline Mourning Warbler (7) & Tree Swallow & \\
\hline Common Yellowthroat (45) & Cliff Swallow & \\
\hline Rose-breasted Grosbeak (11) & Blue Jay (2) & \\
\hline Song Sparrow (3) & American Crow & \\
\hline Brown-headed Cowbird (2) & $\begin{array}{l}\text { White-breasted Nuthatch (1) } \\
\text { House Wren (2) } \\
\text { American Robin } \\
\text { Brown Thrasher } \\
\text { Warbling Vireo } \\
\text { Chestnut-sided Warbler (13) } \\
\text { Rufous-sided Towhee } \\
\text { Clay-colored Sparrow (2) } \\
\text { Red-winged Blackbird } \\
\text { Northern Oriole } \\
\text { American Goldfinch } \\
\end{array}$ & \\
\hline \multicolumn{3}{|c|}{ Brackets indicate number banded if any. } \\
\hline
\end{tabular}

Methods Location is one of the most important considerations to make when setting up a station. A location with a good variety of birds is needed. Many bird species live in the eastern Qu'Appelle Valley. They include Ruffed Grouse, Blue Jay, Tennessee Warbler, Nashville Warbler, American Redstart, Northern Waterthrush, Ovenbird, Mourning Warbler, Chestnut-sided Warbler, Veery, Black-and-white Warbler, Canada Warbler, Rose-breasted Grosbeak and Pileated Woodpecker. In the eastern portion of the Qu'Appelle Valley, these birds find habitat that is similar to parkland habitat found fur- ther north. When birding out of the valley, these species can be difficult to find. That is why I chose the Qu'Appelle Valley.

The particular coulee I net in is quite large. There is a small creek flowing through it with numerous beaver dams and springs along the coulee. In the study area the canopy is mainly Balsam Poplar with Manitoba Maple, Green Ash and some Trembling Aspen. Heavy underbrush consists of Red-Osier Dogwood, Highbush Cranberry and Beaked Hazelnut. It is an undisturbed site with an abundance of other wildlife such 


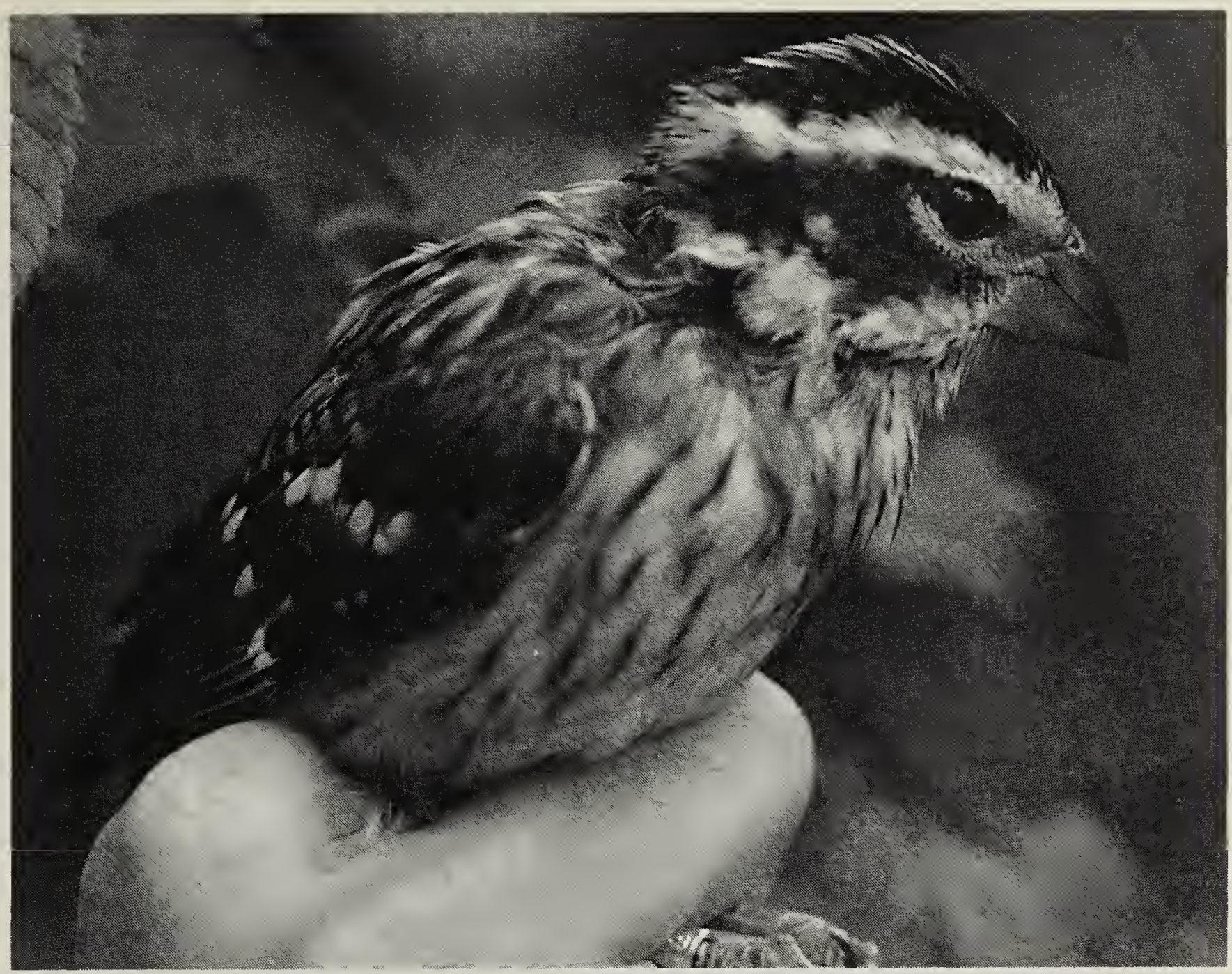

as American Black Bear, Whitetailed Deer, Coyote, Red Squirrel, Beaver and Least Chipmunk being the most noticeable. The Qu'Appelle River is about $800 \mathrm{~m}$ north and grain fields, grassy areas, and marshy areas are all within $200 \mathrm{~m}$ of the study area.

I mistnetted on eight occasions, once every ten days between 31 May and 18 August (each year). I use eight nets that have $30 \mathrm{~mm}$ mesh and are $12 \mathrm{~m} \times 2.6 \mathrm{~m}$ in size. The nets are located in a 5 ha study area at fixed locations. Since I am only concerned with resident birds I do not band during migration. All birds caught are banded. Banding enables me to keep track of the number of individuals in the area by giving each bird its own number. Thus individuals aren't counted more than once and banding birds enables me to determine the number of birds returning from the previous year. I also conduct three-point count censuses each year to identify birds missed by netting. Information from all the MAPS stations is compiled to determine regional population indices, productivity and survivorship of key species.

Since species composition is linked to habitat, vegetation composition and growth are monitored each year to detect forest succession.

Results Table 1 is a list of birds that occurred in or near the study area during 1992, 1993 and/or 1994. Species are considered breeding in the study area based on the following criteria: males singing on territory over a period of at least 20 days (between 6 June-20 July), locally hatched birds observed, birds observed feeding young, and/or birds observed on or building a nest. 


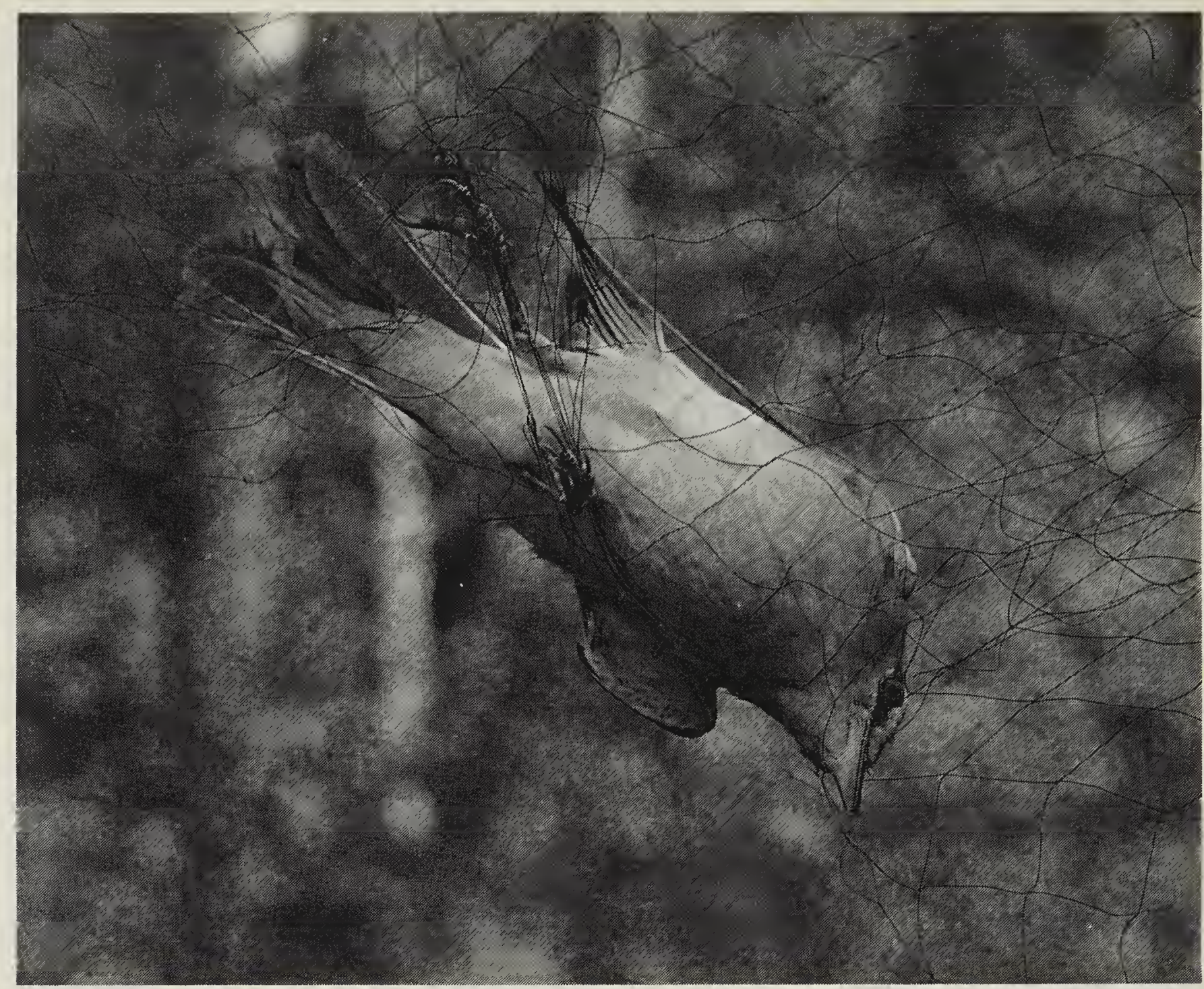

Discussion Although all of these species have been recorded in the Qu'Appelle Valley, I was impressed at the concentration of species in a small area. The heavily wooded coulee habitat on the south side of the valley where there are flowing springs and creeks is extremely productive. Although often inconvenient to get to and full of all kinds of biting insects, these coulees are full of pleasant surprises.

Manley Callin (in Birds of Qu'Appelle) has recorded all of the above species as common to uncommon breeders in the Qu'Appelle Valley with a few exceptions. ${ }^{1}$ Callin records the chat as a rare breeder this far east in the Qu'Appelle Valley. The Mourning Warbler and Canada Warbler are also considered by Callin as rare breeders. Callin considers the Common Raven, Tennessee Warbler, Nashville Warbler, Wilson's
Warbler and Pileated Woodpecker as transient birds.

In 1994 at least one pair of ravens were present in the valley all summer and may have been breeding. Also territorial singing in early July suggests the Tennessee Warbler may be breeding in the area.

By studying local populations of bird species, information to develop keys for aging and sexing songbirds is obtained. As an example, wing chords have limited use for sexing most songbirds. I have found, however, that within the Qu'Appelle study area Red-eyed Vireo wing chords are useful for sexing with very little overlap between the sexes. Keys for aging and sexing songbirds are often inadequate and information from MAPS studies can provide information on plumage, eye colour and bill 
colour that will be helpful in developing regional keys.

At this time it is impossible to determine any local population trends. Perhaps after ten years significant trends might begin to show in the data. On an international basis, however, sufficient data has been collected to show significant trends with some species. This information is available from The Institute For Bird Populations and published in their journal, Bird Trends.

This station in the Qu'Appelle Valley is the only MAPS site in Saskatchewan and one of a handful in western Canada. I find the MAPS site rewarding as it allows me to make a detailed study of local bird populations and their habitat and to contribute to an international bird population monitoring program.
A MAPS station would be ideal for natural history groups to run. It allows for hands-on experience, uses local expertise in flora and fauna and allows for a meaningful research activity.

Acknowledgments Thank you to the Baille Bird-a-thon for their financial assistance, Canadian Wildlife Service and to Al Smith for technical assistance. More information regarding MAPS can be obtained from The Institute For Bird Populations, Box 1346, Point Reyes Station, California 94956-1346, or contact me at my above address.

1. CALLIN, E.M. 1980. Birds of the Qu'Appelle: 1857-1979. Special publ. No. 13, Sask. Natural History Society, Regina.

The water which softens as it circulates through each cell has already been down every river and slept in every ocean. The blood of the land is the river of the body. F. Lehrman. 1988. The sacred landscape. Celestial Arts, Berkeley, $C A$. 